Original Research

\title{
Religiosity and Self-Efficacy in the Prevention of HIV-Risk Behaviours among Muslim University Students
}

\section{Angga Wilandika}

Institute of Health Science 'Aisyiyah Bandung, Indonesia

\begin{abstract}
Introduction: The high prevalence of HIV infection among an age group of 1825 years, both globally or nationally, was indicating students vulnerable to HIV/AIDS infections. Prevention of HIV risk behaviours can be used as a religiosity approach to strengthening the self-efficacy on prevention HIV-risk behaviour. However, there were limited studies on the association between religiosity and self-efficacy on prevention of HIV-risk behaviour among student, especially Muslim students. The aims of this study were to identify the correlation between religiosity with self-efficacy in the prevention of HIV-risk behaviours.
\end{abstract}

Methods: The study employed a correlation study. The sample size comprised 404 Muslim university students with proportionate stratified random sampling. Student's religiosity was measured by The Muslim Piety questionnaire and selfefficacy was measured by Self-Efficacy in the Prevention of HIV-Risk Behaviour questionnaire. Descriptive analysis using mean, standard deviation, percentage and frequency distribution. Meanwhile, inferential analysis using Pearson's Correlation.

Results: The results were found that most of the students have high levels of religiosity and strong self-efficacy in the prevention of high-risk behaviour. Further analysis revealed a significant $(\mathrm{p}<0.005)$ and strong correlations $(\mathrm{r}=$ 0.6780 ) between religiosity and self-efficacy in the prevention of HIV-risk behaviour. Higher levels of religiosity were followed by higher levels of selfefficacy on the prevention of HIV-risk behaviours among students.

Conclusion: findings can be used by academic and health professionals, to implement a religiosity based program to strengthen a self-efficacy of HIV-risk behaviour. Further research can be a focus on the nursing interventions based on religious beliefs to strengthen self-efficacy in the prevention of HIV/AIDS infections.

\section{ARTICLE HISTORY}

Received: Nov 09, 2017

Accepted: Sept 17, 2018

\section{KEYWORDS}

Student; HIV-risk behaviour; Muslim; prevention; religiosity; self-efficacy

\section{CONTACT}

Angga Wilandika

$\bowtie$ wiland.angga@gmail.com $\supseteqq$ Institute of Health Science 'Aisyiyah Bandung, Indonesia

Cite this as: Wilandika, A. (2018). Religiosity and Self-Efficacy in the Prevention of HIV-Risk Behaviours among Muslim University Students. Jurnal Ners, 13 (2), 138-143. doi:http://dx.doi.org/10.20473/in.v13i2.6531

\section{INTRODUCTION}

Globally, the prevalence of HIV infection in young people was increased (CDC, 2010). The increasing incidence of new HIV cases among young people between ages 15-24 years in one year was 30\% (5,000 people) (UNAIDS, 2014).

Meanwhile, in Indonesia, according to Komisi Penanggulangan AIDS Nasional (2015), the number of HIV and AIDS cases was increased from year to year. The number of new infections in 2015 from January to March 2015 was 7212 cases. The prevalence of HIV infection between ages 20-24 years was $15.9 \%$ (Kementerian Kesehatan RI, 2015) or the emerging new cases as many as 1,150 cases $(0.9 \%)$ from the last year (Kementerian Kesehatan RI, 2014).

Although those report does not indicate to the prevalence of HIV/AIDS incident especially among college students, Hightow et al. (2005) revealed that the trend of increasing HIV infection in the age 18-24 years happens to college students. The high numbers of HIV cases among college students have a correlation with their activities that are susceptible to HIV infection. A study about HIV-risk behaviour documented high rates in the college students (Chan, 
Passetti, Garner, Lloyd, \& Dennis, 2011; de Carvalho et al., 2006; Khan et al., 2013).

College students are vulnerable to engage in sexual intercourse outside marriage, drinking alcohol, exchange in a sexual partner, and anal or oral sex (Johnston, O'Malley, Bachman, \& Schulenberg, 2012). In addition, college students' exposure to pornography like watching a porn video and read adult magazines increase the incidence of HIV risk behaviours (Njue, Voeten, \& Remes, 2011).

Survei Kesehatan Reproduksi Remaja Indonesia (SKRRI) 2007 and Survei Demografi dan Kesehatan Indonesia (SDKI) 2012 reported that a young people aged 18-24 are vulnerable to risky behaviours such as sexual intercourse before marriage, smoking, drinking alcohol, and drug abuse (BKKBN, 2012). Similar to Rahmati et al. (2009) that reported a young people in countries with a Muslim majority population has a susceptibility to high-risk behaviours such as drug abuse, drinking alcohol, and high-risk sexual activity.

Based on the findings, it is seen that college students tend to be heavily involved in a riskbehaviours that lead to HIV infection. Therefore, prevention of HIV risk behaviour should be aimed to reduce the cases of HIV infection among college students.

Prevention of HIV risk behaviours can be achieved by college students if there are strong selfbeliefs, or in other words, self-efficacy beliefs. Those who have a strong sense of self-efficacy have confidence in their ability to commit to their goals (Bandura, 2010). Meanwhile, those who have low efficacy would be easy to believe that a task is too difficult to implement (van Dinther, Dochy, \& Segers, 2011).

Nonetheless, Indonesia which has majority Muslim, the incidence of HIV infection would not be depressed just because of their strong Islamic teachings for Muslims (Sern \& Zanuddin, 2014). In fact, there are people who sometimes ignore the teachings of his religion so easily engage in HIV risk behaviours (Hasnain, 2005). In addition, preventionbased religiosity is also sometimes hard done by a Muslim because of adherence to the teachings of his religion and his ability to carry out such practices (Balogun, 2010).

Whereas in Islam, self-beliefs and ability to do something right, is mentioned in the Al-Qur'an Surah Ar-Ra'ad verse 11, means that: “...Indeed, Allah will not change the condition of a people until they change what is in themselves...". Based on the verses of the Al-Qur'an that it is a Muslim should have strong religious beliefs in doing an act.

In addition, there are various other verses of the Al-Qur'an that could become the foundation that a Muslim must have a strong sense of religiosity in performing an action on the basis of piety to Allah as articulated in the QS. Adz-Dzariat verse 56 which means: "... and I did not create the jinn and mankind except to worship Me" and QS. Al-An'am verse 162 which means: "Truly, my prayer and my service of sacrifice, my life and my death, are (all) for Allah, the Cherisher of the Worlds". Hence, a Muslim must be able to make religiousness and obedience to religious teachings as a protection and prevention from various HIV-risk behaviours (Hasnain, 2005).

Observe the various findings above, seen that religiosity had an impact on HIV-risk behaviours, although not specific against self-efficacy in preventing the HIV-risk behaviour. So far, there has been no research that sees the links between religiosity with self-efficacy in the prevention of HIVrisk behaviour among student, especially in the context of Islam. It thus becomes important to further identify the relationship between the level of religiosity among students with self-efficacy in preventing HIV-risk behaviours.

\section{MATERIALS AND METHODS}

This study used a cross-sectional design. This study has passed the ethical clearance of Medical Research Ethics Commission Faculty of Medicine, Universitas Padjadjaran (Ethical Approval Letter Number 454/UN6.C1.3.2/KEPK/PN/2016). The respondents of this study are students at one of the universities in Jatinangor.

The sampling technique approach was used in a proportionate stratified random sampling that is by dividing the population into groups of homogeneous or strata. The sample size of each faculty was taken proportionally according to the number of population in each faculty using the proportional allocation formula. Sample in this study considered several inclusion criteria including: (1) undergraduate and diploma students either in the second year or until the last year, (2) recorded as an active students, (3) Muslims, (4) not students of cooperation or extension classes, and (5) students living with parents or living in boarding houses. The number of samples used in this study as many as 404 Muslim students. Response rate in this study amounted to $95.7 \%$.

The Muslim student's religiosity was measured using the instrument of The Muslim Piety (Hassan, 2007) that has been translated into Bahasa Indonesia. The questionnaire has validity values ranging from $0.354-0.770$ and the reliability value of the Guttman Split-Half coefficient of 0.947 . Meanwhile, self-efficacy was measured using SelfEfficacy in the Prevention of HIV Risk Behaviour Questionnaire, where the questionnaire had validity values ranging from $0.474-0.972$ and the value of the Cronbach's Alpha coefficient ratio of 0.957 . The descriptive analysis uses the calculation of mean, standard deviation, percentage and frequency distribution. Meanwhile, the inferential analysis uses Pearson's Correlation.

\section{RESULTS}

Descriptive analysis was done to see the description of characteristics of university students involved in this research. 
Table 1. University Student's Characteristics ( $\mathrm{n}=$ 404)

\begin{tabular}{lcc}
\hline \multicolumn{1}{c}{ Student's Characteristics } & f & \% \\
\hline The average age is 20.3 years & & \\
Age range 18 - 25 years & & \\
Study Time & & \\
$\quad$ <2 years & 167 & 41,3 \\
$\quad$ > 2 years & 237 & 58,7 \\
Gender & & \\
$\quad$ Man & 169 & 41,8 \\
$\quad$ Women & 235 & 58,2 \\
$\quad$ Current Domicile & & \\
$\quad$ Boarding house & 318 & 78,7 \\
$\quad$ Parent's house & 86 & 21,3 \\
Spouse & & \\
$\quad$ Have spouse & 169 & 41,8 \\
$\quad$ Did not have spouse & 235 & 58,2 \\
$\quad$ Marital Status & & \\
$\quad$ Single & 397 & 98,3 \\
$\quad$ Married & 7 & 1,7 \\
$\quad$ HIV Information Exposure & & \\
$\quad$ Yes & 382 & 94,6 \\
$\quad$ No & 22 & 5,4 \\
\hline
\end{tabular}

Table 2. The Mean of Muslim Religiosity Score and Self-Efficacy in Prevention of HIV-Risk Behaviour $(\mathrm{n}=404)$

\begin{tabular}{cccc}
\hline & mean $\pm \mathbf{D S}$ & f & \% \\
\hline Muslim's Relogiosity & $\mathbf{1 3 , 5 4} \pm \mathbf{2 , 7 0}$ & & \\
Height & $15,06 \pm 1,56$ & 272 & 67,33 \\
Medium & $10,51 \pm 1,53$ & 130 & 32,18 \\
Low & $4,50 \pm 0,71$ & 2 & 0,50 \\
Self-Efficacy & $\mathbf{8 0 , 2 5} \pm \mathbf{8 , 6 5}$ & & \\
Height & $86,73 \pm 5,11$ & 217 & 53,71 \\
Medium & $72,74 \pm 5,14$ & 187 & 46,29 \\
\hline
\end{tabular}

Table 3. The Correlation Test Results between Muslim Religiosity with Self-Efficacy in Prevention of HIV-Risk Behaviour among Students

\begin{tabular}{lcc}
\hline & \multicolumn{2}{c}{$\begin{array}{c}\text { Self-Efficacy in the } \\
\text { Prevention of HIV-Risk } \\
\text { Behaviours }\end{array}$} \\
\cline { 2 - 3 } & $(p)$ & $(r)$ \\
\hline Muslim's Religiosity & 0,000 & 0,687 \\
\hline
\end{tabular}

Students in this study are all Muslim who are studying undergraduate and diploma degree. The age range of students ranged from 18 to 25 years with an average age of 20.3 years. Most of the female students $(58.2 \%)$, said they do not have spouses (58.2\%) and have been studying for more than two years $(58.7 \%)$. In addition, most of the students stayed in boarding houses (78.7\%) and almost all unmarried (98.3\%) and said they had received information about HIV (94.6\%) (Table 1).

In this study, most of the students (67.33\%) were classified as having high religiosity with the average score of $15.06 \pm 1.56$. Similarly, self-efficacy in the prevention of HIV-risk behaviour was found that the majority of college students $(53.70 \%)$ belonged to high self-efficacy with an average score of 86.73 ? 5.11 (Table 2).

The results of Pearson's Product Moment correlation analysis showed statistically significant $(\mathrm{p}=0,000)$ and strong $(\mathrm{r}=0.678)$ with a positive relationship between Muslim religiosity and selfefficacy of prevention of HIV risk behaviour (Table 3 ). In other words, the alternative hypothesis ( $\mathrm{Ha}$ ) is accepted, where higher the religiosity level it will increase the self-efficacy level in the prevention of HIV risk behaviour among the student.

\section{DISCUSSION}

Religiosity is one of the important individual factors that determine students' self-efficacy in the prevention of HIV-risk behaviour. The dimensions of religiosity that include religious beliefs, religious practices, experiential, consequence and devotion, was linked to student's self-efficacy in avoiding HIV risk behaviours. Religious beliefs and religious practices become the decisive aspect of enhancing self-efficacy in preventing risky behaviour among students. Gillum and Holt (2010) suggest that religiosity is the strongest predictor of selfconfidence in the ability to prevent HIV-infected behaviours.

High self-efficacy in the prevention of HIV-risk behaviours will influence students' choices in determining not to engage in the HIV-risk behaviour. The self-efficacy in the prevention of riskbehaviours was observed in this study includes behaviour prevention self-efficacy: extramarital sex, watching pornographic videos, using drugs, using needle tattoo, unwillingness to talk about sexual intercourse, and neglecting the HIV status of a spouse or close friend.

Self-efficacy that was perceived by students in the prevention of HIV risk behaviour encourages students to think, to consider, and to act more appropriately in achieving the goal in avoiding risky behaviours that may arise around them and not engaging in HIV risk behaviours. Schwarzer (2008) argues that self-efficacy is a strong predictor of health behaviour changes. A person with high selfefficacy will be able to achieve the goal of a behaviour, achieve optimal levels of health or avoid a variety of behaviours that can harm yourself.

Students with high self-efficacy will be able to control the situation and conditions in their life including HIV risk behaviour prevention measures. Individuals with high self-efficacy may withstand environmental influences not to engage in risky behaviours such as unsafe sexual activity, sexual intercourse with multiple partners, use of drugs, alcohol use and other health risk activities (Caprara, Regalia, \& Bandura, 2002; Wosinski, 2008). Bogale, Boer, and Seydel (2010) assert that individuals with strong self-efficacy have confidence in the ability to successfully avoid involvement in HIV risk behaviours. 
As described above, in this study, self-efficacy in the prevention of HIV risk behaviour is closely related to the factor of religiosity possessed by students. Students with high levels of religiosity will have self-efficacy in preventing high-risk behaviours of HIV both in cognitive and affective. They will consider more of their actions to avoid engaging in self-harming behaviours.

The religiosity of students was seen and assessed from various forms of worship activities in the life. Religious activity is not only happening when students perform religious ritual practices but also when performing other activities that are driven by power and belief in the Creator and his invisible religious teachings. In this study, the degree of religiosity can be seen or measured based on several domains of religiosity. The religiosity of Muslim students is closely related to the belief in the Rukun Iman dan Rukun Islam.

Safrilsyah, Baharudin, and Duraseh (2010) say that religiosity is closely related to the religious values embedded in human beings which then provide a major role in the development of human character. In the view of Islam, religiosity refers to all dimensions of life, values, dedication and religious practice (Azam, Qiang, Abdullah, \& Abbas, 2011), as mentioned in Al-Qur'an letter of Al-Baqarah verse 208 which means: "O you who believe! enter into Islam whole-heartedly (kaffah)...". Based on the letter of Al-Baqarah verse 208, religiosity is not limited to what is seen in the expression of one's religious behaviour, but must be practised against all aspects of life with all the capabilities possessed. Safrilsyah et al. (2010) say that a religious person must be able to know, understand and interpret all life that has been created by God in order to worship God alone.

The diversity of the level of religiosity in the students can be caused by the experience of religiosity on the students is a personal matter or in other words, only the students themselves who know it. Changes that occur within the student will reflect the level of religiosity in each individual. Students begin to discover personal experiences and beliefs of the divine. On the other hand, changes in values and adjustments that occur during this period can also raise the chances for conflicts and doubts about their religious beliefs.

The significant correlation between religiosity and self-efficacy in preventing HIV risk behaviours suggests that the stability of student-owned religiosity will influence self-belief in its ability to avoid HIV risk behaviours. Religiosity is a dominant aspect related to self-efficacy and preventive measures of HIV/AIDS risk behaviour. Koenig, King, and Carson (2012) who say someone with strong religiosity will have high self-efficacy. On the other hand, high self-efficacy will create a comfortable feeling for his ability to complete a task or an activity so that the stress conditions felt in his life will be reduced. Luquis, Brelsford, and Rojas-Guyler (2012) also say religiosity affects the individual's attitude in dealing with risky behaviour.

Religiosity facilitates the understanding of the individual that affects the goals, actions, and outcomes one anticipates, including self-efficacy (Martin, 2008). According to Davidsdottir and Jonsdottir (2013), a religious person has greater welfare experience, optimism, strong self-efficacy and fewer problems. Further Koenig et al. (2012) says that when a religious person faces a complex problem, they believe that by surrendering to God, they are confident they can overcome the problem and change the situation and they believe in gaining the strength to deal with the adversity. Such beliefs will reduce feelings of helplessness and a feeling of lack of ability to solve problems.

The belief that God has control over all human endeavours in maintaining health will have a positive impact on thinking, self-belief in his ability to successfully conduct health behaviour. Even the belief that God gives self-control over risky behaviours will have an impact on self-assurance or self-efficacy of success in preventing risky behaviours from being able to avoid risky behaviours and avoid adverse consequences (Goggin, Murray, Malcarne, Brown, \& Wallston, 2007; Seybold \& Hill, 2001).

In Islam, religiosity and self-efficacy are also depicted in Al-Qur'an letter al-Baqarah verse 286 which means: "Allah does not charge a soul except (with that within) its capacity. It will have (the consequence of) what (good) it has gained, and it will bear (the consequence of) what (evil) it has earned. "Our Lord, do not impose blame upon us if we have forgotten or erred. Our Lord, and lay not upon us a burden like that which You laid upon those before us. Our Lord, and burden us not with that which we have no ability to bear. And pardon us, and forgive us, and have mercy upon us. You are our protector, so give us victory over the disbelieving people."

Based on the letter of Al-Baqarah verse 286, Allah asserts that everyone will be able to face any task or event that occurs because God promises that will not burden a person but with something in accordance with his ability. Therefore, through belief in God, one will be able to deal with various problems. In the context of prevention of HIV risk behaviours, students with high religiosity will be able to cope with various HIV risk behaviours, as long as they have high self-efficacy, believe in and believe they are capable of such precautions.

Kagimu et al. (2013) say the individual who believes in God can avoid risky behaviours such as pre-marital sexual intercourse and lower the potential for HIV infection. Similarly, Goggin et al. (2007) and James and Wells (2003), argue that religious beliefs affect a person's awareness, cognition and emotions when doing something. Someone through the cognitive process will collect various information, weigh the pros and cons and 
strengthen self-efficacy on whether to perform a risky behaviour or not.

As for how religiosity plays a role in improving self-efficacy prevention of HIV risk behaviour associated with fear of God when will do something that is not good. Kagimu et al. (2013) reported that religiosity works by instilling fear in God to avoid His punishment. Where a religious person believes that God sees and observes his every action, as it is written in the Qur'an Al-Hujurat verse 108 which means: "O you who have believed, do not put (yourselves) before Allah and His Messenger but fear Allah . Indeed, Allah is Hearing and Knowing".

The way religiosity works against self-efficacy and HIV infection prevention behaviours is illustrated as follows: creating a fear of God and His punishment for those who disobey Him as well as embarrassment when they do the forbidden things; encouraging obedience to God; creating the feeling that God is seeing everyone; and encourage selfcontrol and increase the self-efficacy of self-efficacy resulting in inner fighting to avoid risky behaviour (Kagimu et al., 2013).

High levels of student religiosity will strengthen self-efficacy in the prevention of sexual behaviour outside of marriage, watching pornographic videos, using drugs, using tattoo needles, unwillingness to talk about sexual intercourse, and neglecting partner's HIV status among college students. With strong self-efficacy in college students, so they can take precautions at risk of HIV.

\section{CONCLUSION}

The results of this study conclude a strong and significant positive relationship between Muslim religiosity and self-efficacy prevention of HIV-risk behaviour among students. Therefore, the alternative hypothesis (Ha) is accepted. Thus, the higher the Muslim religiosity will be followed by the higher self-efficacy of prevention of HIV risk behaviour among students. The results of this study can be used by academics, universities and health practitioners such as nurses in the development of religious spiritual based coaching programs aimed at increasing the self-confidence of each college student's individual ability to avoid behaviours that can lead to HIV infection in the campus environment.

The limitation of this study lies in the place of study which is only done in one place. This study only involves students from one university so that the results of the research cannot describe widely. In addition, there is no standard instrument that specifically measures the self-efficacy of HIV-risk behaviour prevention. Therefore, researchers develop instruments to measure the self-efficacy. However, to ensure the reliability of these instruments, then have tested the instrument that includes the validity and reliability test. Instrument test results show that the instrument is reliable and appropriate measures of self-efficacy prevention of HIV risk behaviours among university students.

\section{REFERENCES}

Azam, A., Qiang, F., Abdullah, M. I., \& Abbas, S. A. (2011). Impact of 5-D of religiosity on diffusion rate of innovation. International Journal of Business and Social Science, 2(17).

Balogun, A. S. (2010). Islamic perspectives on HIV/AIDS and antiretroviral treatment: the case of Nigeria. African Journal of AIDS Research, 9(4), 459-466. doi: 10.2989/16085906.2010.546764

Bandura, A. (2010). Self-efficacy. In I. B. Weiner \& W. E. Craighead (Eds.), The Corsini Encyclopedia of Psychology (Vol. 4, pp. 1534-1536). Hoboken, New Jersey: John Wiley \& Sons.

BKKBN. (2012). Survei Demografi dan Kesehatan Indonesia (SDKI) 2012. Jakarta.

Bogale, G. W., Boer, H., \& Seydel, E. R. (2010). Condom use among low-literate, rural females in Ethiopia: the role of vulnerability to HIV infection, condom attitude, and self-efficacy. AIDS care, 22(7), 851-857. doi: 10.1080/09540120903483026

Caprara, G. V., Regalia, C., \& Bandura, A. (2002). Longitudinal impact of perceived self-regulatory efficacy on violent conduct. European Psychologist, 7(1), 63.

CDC. (2010). Diagnoses of HIV infection and AIDS in the United States and dependent areas, 2009 HIV Surveillance Report (Vol. 21): Centers for Disease Control.

Chan, Y.-f., Passetti, L. L., Garner, B. R., Lloyd, J. J., \& Dennis, M. L. (2011). HIV Risk Behaviours: Risky Sexual Activities and Needle Use Among Adolescents in Substance Abuse Treatment. AIDS and Behaviour, 15(1), 114-124. doi: http://dx.doi.org/10.1007/s10461-010-9702-3

Davidsdottir, S., \& Jonsdottir, L. S. (2013). Religion and Well-Being. British Journal of Arts and Social Sciences, 11 (2), 186-198.

de Carvalho, F. T., Neiva-Silva, L., Ramos, M. C., Evans, J., Koller, S. H., Piccinini, C. A., \& Page-Shafer, K. (2006). Sexual and drug use risk behaviours among children and youth in street circumstances in Porto Alegre, Brazil. AIDS and Behaviour, 10(1), 57-66.

Gillum, R., \& Holt, C. L. (2010). Associations between religious involvement and behavioural risk factors for HIV/AIDS in American women and men in a national health survey. Annals of Behavioural Medicine, 40(3), 284-293.

Goggin, K., Murray, T. S., Malcarne, V. L., Brown, S. A., \& Wallston, K. A. (2007). Do religious and control cognitions predict risky behaviour? I. Development and validation of the Alcoholrelated God Locus of Control Scale for Adolescents (AGLOC-A). Cognitive Therapy and Research, 31(1), 111-122.

Hasnain, M. (2005). Cultural Approach to HIV/AIDS Harm Reduction in Muslim Countries. Harm reduction journal, 2(1), 1-8. doi: 10.1186/14777517-2-23 
Hassan, R. (2007). On Being Religious: Patterns of Religious Commitment in Muslim Societies. The Muslim World, 97(3), 437-478. doi: 10.1111/j.1478-1913.2007.00190.x

Hightow, L. B., MacDonald, P. D., Pilcher, C. D., Kaplan, A. H., Foust, E., Nguyen, T. Q., \& Leone, P. A. (2005). The unexpected movement of the HIV epidemic in the Southeastern United States: transmission among college students. JAIDS Journal of Acquired Immune Deficiency Syndromes, 38(5), 531-537.

James, A., \& Wells, A. (2003). Religion and mental health: Towards a cognitive-behavioural framework. British journal of health psychology, 8(3), 359-376.

Johnston, L. D., O'Malley, P. M., Bachman, J. G., \& Schulenberg, J. E. (2012). Monitoring the Future national results on adolescent drug use: Overview of key findings, 2011. Institute for Social Research.

Kagimu, M., Guwatudde, D., Rwabukwali, C., Kaye, S., Walakira, Y., \& Ainomugisha, D. (2013). Religiosity for Promotion of Behaviours Likely to Reduce New HIV Infections in Uganda: A Study Among Muslim Youth in Wakiso District. Journal of religion and health, 52(4), 1211-1227. doi: http://dx.doi.org/10.1007/s10943-011-9563-8

Kementerian Kesehatan RI. (2014). Laporan Situasi Perkembangan HIV/AIDS di Indonesia Triwulan IV Tahun 2014. Ditjen PP \& PL Kementerian Kesehatan Republik Indonesia.

Kementerian Kesehatan RI. (2015). Laporan Situasi Perkembangan HIV-AIDS di Indonesia Triwulan I Tahun 2015. Ditjen PP \& PL Kementerian Kesehatan Republik Indonesia.

Khan, M. R., Berger, A., Hemberg, J., O’Neill, A., Dyer, T. P., \& Smyrk, K. (2013). Non-injection and injection drug use and STI/HIV risk in the United States: the degree to which sexual risk behaviours versus sex with an STI-infected partner account for infection transmission among drug users. AIDS and Behaviour, 17(3), 11851194

Koenig, H. G., King, D., \& Carson, V. B. (2012). Handbook of religion and health: Oxford university press.

Komisi Penanggulangan AIDS Nasional. (2015). Laporan Kegiatan KPAN 2014. Komisi Penanggulangan AIDS Nasional (KPAN).
Luquis, R. R., Brelsford, G. M., \& Rojas-Guyler, L. (2012). Religiosity, spirituality, sexual attitudes, and sexual behaviours among college students. Journal of religion and health, 51(3), 601-614.

Martin, F. (2008). Psychology, religion and development: a literature review. RAD Working Paper 25.

Njue, C., Voeten, H. A., \& Remes, P. (2011). Porn video shows, local brew, and transactional sex: HIV risk among youth in Kisumu, Kenya. BMC public Health, 11(1), 635.

Rahmati, N. K. F., Niknami, S., Amin, S. F., Ahmadi, F., Jafari, M., \& Rahnama, P. (2009). The implication of health belief model in planning educational programmes for preventing HIV/AIDS among university students. PAYESH Health Monitor, 8(4).

Safrilsyah, S., Baharudin, R., \& Duraseh, N. (2010). Religiusitas dalam Persfektif Islam: Suatu Kajian Psikologi Agama. Substantia, 12(2).

Schwarzer, R. (2008). Modeling health behaviour change: How to predict and modify the adoption and maintenance of health behaviours. Applied Psychology, 57(1), 1-29.

Sern, T. J., \& Zanuddin, H. (2014). Affirmative Religious Response Culture to HIV and AIDS: Understanding the Public Relations Role of JAKIM in Curbing the Epidemic among Young Muslim Couples in Malaysia. Asian Social Science, 10(13), 8.

Seybold, K. S., \& Hill, P. C. (2001). The role of religion and spirituality in mental and physical health. Current Directions in Psychological Science, 10(1), 21-24.

UNAIDS. (2014). Global report: UNAIDS report on the global AIDS epidemic 2013. Joint United Nations Programme on HIV/AIDS Geneva.

van Dinther, M., Dochy, F., \& Segers, M. (2011). Factors affecting students' self-efficacy in higher education. Educational research review, 6(2), 95108.

Wosinski, J. (2008). HIV Risk Among Nursing Students in Rwanda: Self-efficacy, Knowledge and Attitudes. (Doctoral Dissertation), Loma Linda University, United State. Retrieved from https://books.google.co.id/books?id=HR3NrfyV4 $\underline{\mathrm{S} 8 \mathrm{C}}$ 